\title{
Molybdenum uptake in Escherichia coli K12
}

\author{
Guillermo Lopez Corcuera, Marco Bastidas and Michel Dubourdieu* \\ Universidad de Los Andes, Facultad de Ciencias, Departamento de Biologia, Mérida-5101, Venezuela
}

(Received 17 August 1992; revised 16 March 1993; accepted 19 March 1993)

\begin{abstract}
Molybdenum uptake was examined in Escherichia coli $\mathrm{K} 12$ using the radionuclide ${ }^{99} \mathrm{Mo}$. The molybdenum uptake system was characterized in an unusual chlD strain, which appeared to be normal in uptake of the $\mathrm{MoO}_{4}^{2-}$ ion but altered in subsequent molybdenum processing. As a consequence, molybdenum could be chased from cells in the chlD strain, while it was irreversibly assimilated in the wild-type strain. Molybdenum uptake showed a biphasic kinetic curve, with a very rapid binding followed by a slow uptake phase. The uptake appeared to involve an active transport system. Molybdenum, probably in the form of molybdate, accumulated by a factor of about 30 in the cells. An energy source was necessary and uptake was inhibited by arsenate, but not by CCCP (carbonyl cyanide $m$-chlorophenylhydrazone). The uptake system saturated with a $K_{\mathrm{m}}$ of 2.5-2.7 $\times 10^{-8} \mathrm{M}$. Uptake seemed to depend on a periplasmic binding protein, since cold shock treatment and arsenate abolished uptake. A molybdate binding protein activity was detected in the periplasmic fluid with a $K_{\mathrm{b}}$ of $9 \mathrm{nM}$. Sulphate inhibited uptake and the uptake activity was pH dependent, with an apparent $\mathrm{pK}$ of 6.7. These results imply that molybdate transport belongs to the family of energy-dependent periplasmic binding protein systems. An explanation for the peculiar behaviour of the chlD strain used in this work is proposed.
\end{abstract}

\section{Introduction}

Several molybdoenzymes have been described in Escherichia coli (Iida \& Taniguchi, 1959; Forget, 1974; Enoch \& Lester, 1975; Lund \& DeMoss, 1976; del Campillo-Campbell \& Campbell, 1982; Stewart \& MacGregor, 1982). Two molybdoenzymes, nitrate reductase and formate dehydrogenase, which belong to the respiratory chain of nitrate dissimilation (Pichinoty, 1964; Ruiz-Herrera \& DeMoss, 1969; Sánchez et al., 1979 ), are essential in the anaerobic energetics of $E$. coli. All these enzymes apparently depend on the presence of the same molybdo-cofactor (Johnson et al., 1980). The cofactor has been purified and characterized as a sulphate-containing pterin (Johnson et al., 1984; Johnson \& Rajagopalan, 1987b).

The activity of these enzymes is pleiotropically lost in several types of chlorate-resistant mutants (Puig \& Azoulay, 1967; Adhya et al., 1968; Venables \& Guest, 1968; Casse, 1970; Dagert \& Puig, 1976; Johnson \& Rajagopalan, 1987a). These chlD mutants were the first to be suspected to have an altered metabolism of

\footnotetext{
*Author for correspondence. Tel. 74 401310; fax 74401286 .
}

Abbreviation: CCCP, carbonyl cyanide in-chlorophenylhydrazone. molybdenum (Glaser \& DeMoss, 1972), since they showed the wild-type phenotype in the presence of high molybdate concentrations. Extracts of $c h l B$ cells were shown to produce an active nitrate reductase in the presence of a cell extract containing the molybdocofactor (MacGregor \& Schnaitman, 1973). It was concluded that all pleiotropic chlorate-resistant mutants were affected in their molybdenum metabolism (Dubourdieu et al., 1976; Johnson et al., 1980; Stewart, 1982). Unfortunately, the precise metabolism of this metal in $E$. coli is unknown and the nature of the functions lost in the pleiotropic chlorate-resistant mutants is unclear: chlA and chlE could participate in the synthesis of the molybdo-cofactor (Casse, 1970; Miller \& Amy, 1983), chlB could incorporate this cofactor into molybdenum-requiring enzymes (Giordano et al., 1980) and chlD could be involved in the uptake of molybdenum (Johann \& Hinton, 1987; Scott \& Amy, 1989), although other roles have been suggested (Sperl \& DeMoss, 1975). Molybdenum uptake has been studied primarily in nitrogen-fixing bacteria such as Clostridium pasteurianum (Elliot \& Mortenson, 1975, 1976), Azotobacter vinelandii and Klebsiella pneumoniae (Pienkos \& Brill, 1981). Nitrogenase contains a completely different cofactor and, in general, is not affected in a pleiotropic way in chlorate-resistant mutants, with 
the exception of chlD (Eady \& Postgate, 1974). In E. coli only indirect data are available (Johann \& Hinton, 1987; Scott \& Amy, 1989; Lee et al., 1990).

As an approach to studying molybdenum metabolism in $E$. coli, we investigated uptake of ${ }^{99} \mathrm{MoO}_{4}^{2-}$ by the wildtype strain and some chlorate-resistant mutants. A chlD mutant strain was able to take up molybdenum and to release it into the medium, indicating that, in this strain, intracellular molybdenum was untransformed, but in the wild-type strain it was irreversibly sequestered.

\section{Methods}

Strains and culture media. E. coli $\mathrm{K} 12$ strain $356\left(\mathrm{~F}^{-}\right.$thr leu his arg pro ade lacY galB $/ T_{1} \lambda\left(\lambda^{-}\right) / \mathrm{Str}^{\mathrm{R}}$ ) (E. Wollman) and strain $356_{22}$, a spontaneous chlD mutant strain, obtained by J. Puig from strain 356 (Dubourdieu et al., 1976), were used. Cells were grown anaerobically at $37^{\circ} \mathrm{C}$ in a medium containing $\left(\mathrm{g} \mathrm{l}^{-1}\right): \mathrm{KH}_{2} \mathrm{PO}_{4}, 3 \mathrm{~g} ; \mathrm{K}_{2} \mathrm{HPO}_{4} \cdot 3 \mathrm{H}_{2} \mathrm{O}$, $5.1 \mathrm{~g}$; sodium citrate $2 \mathrm{H}_{2} \mathrm{O}, 0.56 \mathrm{~g} ; \mathrm{MgSO}_{4} .7 \mathrm{H}_{2} \mathrm{O}, 0.2 \mathrm{~g} ;\left(\mathrm{NH}_{4}\right)_{2} \mathrm{SO}_{4}$, $1.0 \mathrm{~g}$; glucose, $0.08 \mathrm{~g}$; vitamin $\mathrm{B}_{1}, 0.01 \mathrm{~g}$; adenine, $0.05 \mathrm{~g}$; and amino acids, $0.08 \mathrm{~g}$. Cells were collected by centrifugation at mid-exponential phase at an optical density (OD) at $600 \mathrm{~nm}$ of about $0 \cdot 3-0 \cdot 5$.

Uptake experiments. After washing with phosphate buffer $(0.01 \mathrm{M}$, pH 6.5), cells were resuspended in the same buffer $(1.2$ to $2 \mathrm{ml})$ at an $\mathrm{OD}_{600}$ of 1.0 and kept on ice. Before use, cells were incubated for $30 \mathrm{~min}$ in this buffer at $25^{\circ} \mathrm{C}$. Glucose was added $\left(20 \mathrm{mg} \mathrm{ml}^{-1}\right)$ and the mixture incubated for $10 \mathrm{~min}$ at $25^{\circ} \mathrm{C}$ in a narrow-necked tube without shaking. Uptake was initiated by the addition of approximately $2 \times 10^{-8} \mathrm{M}^{-99} \mathrm{Mo}$ at about 3-6 $\times 10^{5}$ c.p.m. $\mathrm{ml}^{-1}$. Carrier-free radioactive ${ }^{99}$ Mo was obtained from SORIN (Saclay, France) or Union Carbide. At intervals, a $100 \mu$ l sample was withdrawn, deposited on cellulose acetate filters ( $25 \mathrm{~mm}$ diameter, $0.45 \mu \mathrm{m}$ pore size, Millipore) and washed under vacuum with $10 \mathrm{ml}$ of phosphate buffer. The whole process of sampling, filtering and washing lasted less than $10 \mathrm{~s}$. The filters were dried and counted in a gamma counter (Packard) using only the gamma emission at $740 \mathrm{keV}$. Radioactivity present on a filter varied from $10^{3}$ to $10^{4}$ c.p.m. The volume of washing buffer that gave the most reproducible values was $5-10 \mathrm{ml}$. Nitrate and acetate were added to the wash buffer, but did not alter the results. Filters from tubes that required more than $5 \mathrm{~s}$ filtering time were discarded since the washing time was found to affect the results. The non-specific retention of molybdate by the filters was determined in triplicate in each experiment by filtering and washing the same sample of radioactive molybdate, but without cells. Cellulose acetate filters retained less molybdate than filters made of cellulose nitrate. In all cases, the data presented are the means of three separate experiments. The variation was generally between 20 and $40 \%$. When performing uptake experiments at different $\mathrm{pH}$ values, the $\mathrm{pH}$ of the phosphate buffer was modified by adding $\mathrm{NaOH}$ or $\mathrm{HCl}$. Chase experiments were always performed after uptake had reached equilibrium by adding non-radioactive molybdate at a concentration about 1000 -fold higher than the initial radioactive molybdate. In some cases, cells were de-energized by incubating them, prior to the uptake experiment, in the presence of $5 \times 10^{-5} \mathrm{M}$-sodium azide and $5 \times 10^{-5} \mathrm{M}$-dinitrophenol at $37^{\circ} \mathrm{C}$ for $24 \mathrm{~h}$, with shaking. These cells were then washed and resuspended as described. All the inhibitors used were added at the same time as the glucose. The accumulation factor was defined as the ratio between the concentrations of cellular molybdenum, corresponding to the second phase of the uptake curve, and external molybdate $\left({ }^{99} \mathrm{MoO}_{4}^{2-}\right.$ added to the transport medium). Intracellular volume was estimated (according to Kepes, 1978) to be $0.84 \mu \mathrm{l}$ intracellular water in $1 \mathrm{ml}$ of medium at an $\mathrm{OD}_{600}$ of $1 \cdot 0$.
Cold shock treatment. This was performed according to Neu \& Heppel (1965) using cell suspensions prepared as for uptake experiments, except that after the radioactive molybdate was added, incubation was for $15-30 \mathrm{~min}$. Cells were then centrifuged at $5000 \mathrm{~g}$ for $10 \mathrm{~min}$, washed once with $0.06 \mathrm{M}$-phosphate buffer, $\mathrm{pH} 7 \cdot 1$, and centrifuged a second time. Then cells were resuspended in 1 vol. $0.03 \mathrm{M}-$ Tris/ $\mathrm{HCl}$ buffer, $\mathrm{pH} 7.1(30 \mathrm{ml}$ buffer per $\mathrm{g}$ wet wt cells) and this suspension was mixed with $1 \mathrm{vol}$. of the same buffer containing $40 \%$ (w/v) sucrose and $10^{-3} \mathrm{M}$-EDTA. The suspension was shaken at room temperature for $10 \mathrm{~min}$, centrifuged at $5000 \mathrm{~g}$ for $10 \mathrm{~min}$, and the supernatant fluid counted for radioactivity. The pelleted cells were resuspended in $0.5 \mathrm{~mm}-\mathrm{MgCl}_{2}(40 \mathrm{ml}$ per $\mathrm{g}$ wet cells $)$ and kept at $0{ }^{\circ} \mathrm{C}$. After incubation at $0^{\circ} \mathrm{C}$ for $20 \mathrm{~min}$, the cells were centrifuged and the supernatant fluid (or cold shock liquid) was counted. Cell spheroplasts were disrupted and centrifuged at $100000 \mathrm{~g}$ for $90 \mathrm{~min}$ to separate the cytoplasmic fraction from the membranes. Protein was determined by the Coomassie blue method (Sedmak \& Grosberg, 1977).

Equilibrium dialysis experiment. Periplasmic fluid, concentrated 100fold, was used in a custom-built apparatus containing 10 pairs of dialysis cells. Each pair of cells $(400 \mu$ in total) was divided into two compartments by a dialysing membrane. Concentrated periplasmic fluid $(100 \mu \mathrm{l})$ and $0.06 \mathrm{M}$-phosphate buffer, $\mathrm{pH} 7.0(100 \mu \mathrm{l})$ were added to one of the compartments of each pair. The same buffer containing the desired molybdate concentration, together with radioactive molybdate in a volume of $200 \mu \mathrm{l}$ was added to the other compartment. Mixing was attained by placing glass beads in each compartment. Equilibrium was attained after $24-48 \mathrm{~h}$ incubation of room temperature. Samples $(50 \mu \mathrm{l})$ were then withdrawn from each compartment and counted. The radioactivity found in the compartment without extract determined free molybdate concentration at equilibrium, while the difference in radioactivity between the two compartments of a pair determined protein-bound molybdate.

\section{Results}

\section{Optimization of the experimental conditions for molybdenum uptake}

The first uptake curves obtained gave high variability (up to $90 \%$ ), which was not observed in a parallel proline transport experiment. Several parameters were examined and the optimum conditions were found to be the use of cellulose acetate filters, not less than $5 \mathrm{ml}$ of washing buffer (we used $10 \mathrm{ml}$ ), addition of the cell sample just after addition of the washing buffer, constant filtering time (4-5 s), and addition of glucose. In this way the variability was minimized $(90 \%$ of the determinations had a variability of less than $30 \%$ ), but not eliminated. All determinations were therefore performed simultaneously in triplicate and most of the experiments were performed more than twice.

$\mathrm{MoO}_{4}^{2-}$ uptake was first assayed in the wild-type strain with molybdate concentrations between $2 \times 10^{-8} \mathrm{M}$ and $5 \times 10^{-7} \mathrm{M}$. The uptake occurred in two phases (Fig. 1); a very rapid one (instantaneous under our conditions), followed by a slow increase. The process was essentially irreversible, since less than $10 \%$ of total radioactivity accumulated after $12 \mathrm{~min}$ of incubation could be liberated in an exchange experiment in the presence of $10^{-5} \mathrm{M}$ non-radioactive molybdate (Fig. 1). 


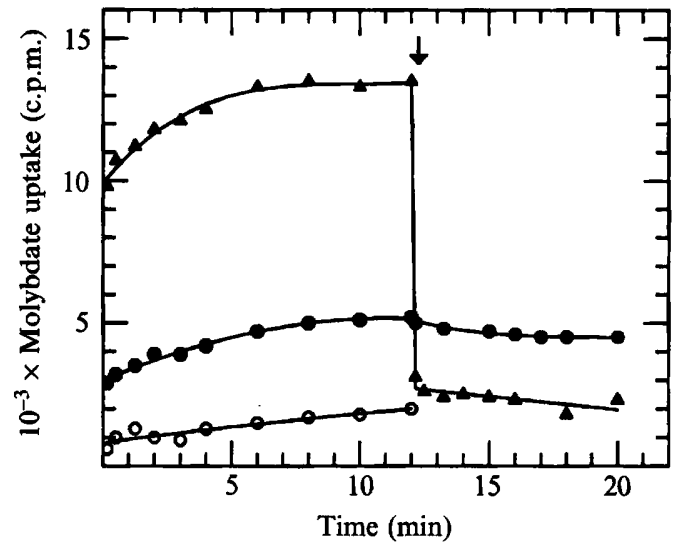

Fig. 1. Molybdenum uptake by the $c h l D$ mutant $(\boldsymbol{A})$ and the wild-type strain (O). Initial $\mathrm{MoO}_{4}$ concentration was $2 \times 10^{-8} \mathrm{M}$, in the presence of about $5 \times 10^{5}$ c.p.m. (ml bacterial suspension $)^{-1}\left(O_{600}=1 \cdot 0\right)$. Time was counted from the time of molybdate addition. Samples $(100 \mu l)$ were withdrawn at various times and filtered as described in Methods. After reaching the equilibrium, a chase was performed by adding nonradioactive molybdate at a final concentration of $10^{-5} \mathrm{M}$ (arrow). The control curve $(O)$ was obtained with the chlD strain under conditions of repression of the molybdate transport system (see Fig. 4).

\section{Some properties of the molybdate uptake system}

The above results show that the wild-type strain is not suitable for studying molybdenum transport, as molybdenum was not found in the cell in an osmotically active form, either as a consequence of irreversible binding or, more probably, due to chemical transformation. Several chlorate-resistant mutants were grown and assayed for $\mathrm{MoO}_{4}^{2-}$ uptake under the same conditions as those used with the wild-type strain. Our chlD strain (Dubourdieu et al., 1976) could exchange most of the cellular ${ }^{99} \mathrm{Mo}$ when chased with non- radioactive molybdenum (Fig. 1). In this strain, the time course of uptake had two phases, which were more obvious than in the wild-type strain. The quantity of $\mathrm{MoO}_{4}^{2-}$ captured during the first phase was several times higher than in the wild type strain and was complete within $5 \mathrm{~s}$ (the minimum time necessary to perform the first filtration after molybdate addition), possibly indicating the binding of molybdenum to some receptor. The second phase resembled a pseudo-first-order event with a half-life of about $90 \mathrm{~s}$ at an $\mathrm{MoO}_{4}^{2-}$ concentration of $2 \times 10^{-8} \mathrm{M}$.

These results were surprising since chlD locus is generally considered responsible for molybdenum uptake (Scott \& Amy, 1989; Hinton \& Dean, 1990) but could be explained by the nature of the mutation, which might affect only one gene of this complex locus (Johann \& Hinton, 1987; Hinton \& Dean, 1990). This chlD strain was used in the following uptake experiments, since molybdenum transport would not depend on the molybdenum previously assimilated during growth; it is difficult to obtain a medium free (e.g. $<1 \mathrm{nM}$ ) of molybdate.

Uptake was measured as a function of the incubation temperature in the presence of $20 \mathrm{nM}-\mathrm{MoO}_{4}^{2-}$. On lowering the temperature, the rate of phase 2 uptake decreased until, at $0^{\circ} \mathrm{C}$, only the first phase was present (results not shown), indicating that this phase does not correspond to an enzymic process. The second phase of $\mathrm{MoO}_{4}^{2-}$ uptake was clearly dependent on $\mathrm{pH}$ (optimum 6.0-6.2), while the first phase was insensitive to $\mathrm{pH}$ change. The phosphate buffer of the transport assay was replaced with $50 \mathrm{~mm}$-Tris/ $\mathrm{HCl}$ without producing any detectable change in the time-dependent uptake curves. Sulphate $(10 \mu \mathrm{M})$ decreased both the rate and amount of

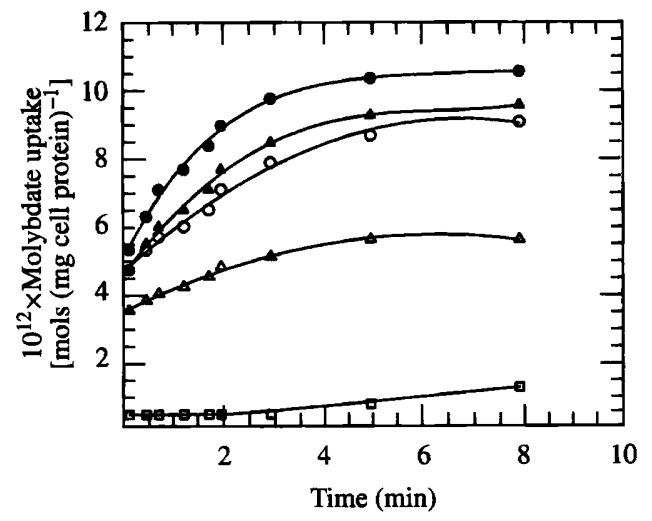

Fig. 2

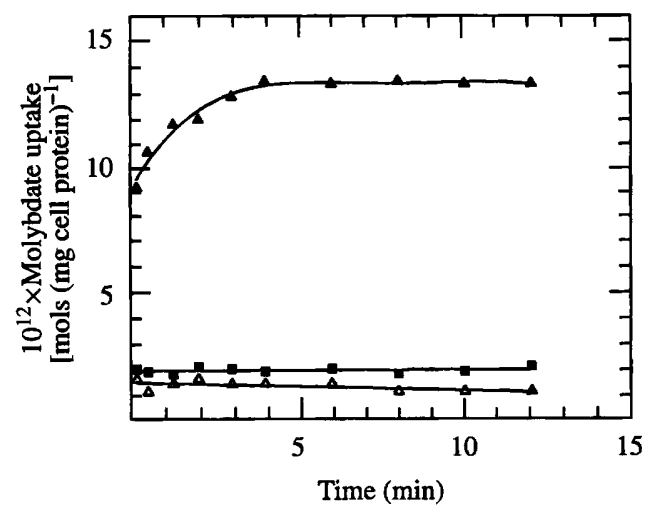

Fig. 3

Fig. 2. Effect of some metabolic inhibitors on molybdenum uptake by the chlD strain. The assay conditions were the same as those in Fig. 1. $\triangle$, No inhibitor; $\bigcirc, 2 \times 10^{-6} \mathrm{M}$-CCCP; other curves, arsenate at $5 \times 10^{-4}(\odot), 5 \times 10^{-3}(\triangle)$ and $1 \times 10^{-1}(\square) \mathrm{M}$, respectively.

Fig. 3. Effect of a cold shock treatment on molybdenum uptake by the chlD strain. The general assay conditions were the same as in Fig. 1. In this case, a sample of harvested cells was first assayed for uptake without treatment $(\boldsymbol{\Delta})$; the remaining cells were subjected to EDTA-sucrose treatment $(\square)$ and then to an osmotic shock in cold water $(\Delta)$, uptake being after each treatment. 
phase 2 uptake by $45 \%$, but did not affect the phase 1 (data not show). These results suggest that phase 2 represents the transport process, while phase 1 may reflect simple binding.

\section{Energy dependence}

In the chlD strain the accumulation ratio was about 30 at $10 \mathrm{~nm}$ external $\mathrm{MoO}_{4}^{2-}$. Glucose $(2 \%, \mathrm{w} / \mathrm{v})$ was added routinely; if it was omitted, the rate of uptake was diminished, but not abolished. However, when the cells were treated with dinitrophenol and azide, $\mathrm{MoO}_{4}^{2-}$ was not taken up unless the cell suspension was incubated in the presence of glucose (data not shown). CCCP did not affect uptake at $2 \mu \mathrm{M}$ (a concentration known to almost eliminate the electrical potential difference, $\Delta \psi$, of the cell; Yoshi et al., 1989) (Fig. 2). Conversely, arsenate produced a $65-70 \%$ inhibition of uptake when used at $5 \mathrm{mM}$, in the presence of $10 \mathrm{~mm}$-phosphate. This is close to the predicted inhibition of $50 \%$ when equal concentrations of arsenate and phosphate are used (Kepes, 1978). It is unlikely that the effect of arsenate was due to competition with $\mathrm{MoO}_{4}^{2-}$ since phosphate (an analogue of arsenate) did not affect the uptake. Binding was only slightly affected at this concentration of arsenate. Most authors use phosphate-free buffers in the presence of arsenate, which might explain the high inhibition obtained with only $100 \mu \mathrm{M}$-arsenate (Klein \& Boyer, 1972; Berger, 1973; Berger \& Heppel, 1974). The even higher sensitivity to arsenate observed by Yoshi et al. (1989) is due to the use of EDTA-treated cells (which do not take up molybdate Fig. 3), together with a phosphate-free buffer.

\section{Effect of cold shock treatment}

Sensitivity to osmotic shock in transport systems is due to the involvement of periplasmic binding proteins (Berger \& Heppel, 1974; Ames, 1986). The cold shock treatment liberates external molecules in two steps (Neu \& Heppel, 1965). First there is an EDTA-dependent depletion of cations in the outer membrane, followed by the cold-shock-dependent release of periplasmic components. Both phases of $\mathrm{MoO}_{4}^{2-}$ uptake were completely abolished by cold shock, and by the EDTA treatment alone (Fig. 3). These results imply the participation of periplasmic components in $\mathrm{MoO}_{4}^{2-}$ uptake. Proline transport, assayed under the same conditions, was essentially unaffected by the osmotic shock.

The periplasmic fluid was concentrated 100 -fold and assayed for $\mathrm{MoO}_{4}^{2-}$ binding activity by equilibrium dialysis, using four molybdate concentrations (results not shown). A $K_{\mathrm{D}}$ of $9 \mathrm{nM}$ for $\mathrm{MoO}_{4}^{2-}$ was calculated.

In another experiment both the chlD and the wild-type
Table 1. Distribution of molybdenum in chlD and wildtype strains

The experiment was performed on cells resuspended at an $\mathrm{OD}_{600}$ of 1.0 , which corresponds to $131 \mu \mathrm{g}$ protein $\mathrm{ml}^{-1}$ for the chlD strain and $120 \mu \mathrm{g}$ protein $\mathrm{ml}^{-1}$ for the wild-type strain. A $1 \mathrm{ml}$ volume of cells was incubated at room temperature in the presence of $10^{-8} \mathrm{M}-\mathrm{MoO}_{4}^{2-}$ molybdate and ${ }^{99} \mathrm{Mo}$ for $30 \mathrm{~min}$, and then subjected to a cold shock treatment. The supernatants resulting from the EDTA treatment and from osmotic shock were saved and aliquots were counted. Results are expressed as mols of molybdenum present in $1 \mathrm{ml}$ of the initial cell suspension.

\begin{tabular}{lcc}
\hline \hline & \multicolumn{1}{c}{$10^{13} \times$ Molybdenum concn $\left(\mathrm{mol} \mathrm{ml}^{-1}\right)$} \\
\cline { 2 - 3 } & Wild-type & chlD \\
\hline Washed bacteria & $10 \cdot 7(100 \%)$ & $30.1(100 \%)$ \\
Supernatant of & $3.9(37 \%)$ & $24.5(81 \%)$ \\
EDTA treatment & & \\
Cold shock fluid & $1.8(17 \%)$ & $4 \cdot 0(13 \%)$ \\
Cold shock & $3.4(32 \%)$ & $4.4(15 \%)$ \\
treated cells & & \\
\hline \hline
\end{tabular}

strains were incubated with radioactive and $20 \mathrm{nM}$ nonradioactive $\mathrm{MoO}_{4}^{2-}$. After 30 min, cells were subjected to EDTA treatment and cold shock disruption, and the radioactive $\mathrm{MoO}_{4}^{2-}$ associated with each cellular compartment was determined (Table 1). The chlD strain accumulated three times more molybdenum than the wild-type strain. However, its intracellular level of molybdenum after the cold shock treatment was similar to that of the wild-type strain. The excess $\mathrm{MoO}_{4}^{2-}$ accumulated in the chlD strain was found in the EDTA fluid. The $\mathrm{MoO}_{4}^{2-}$ released in the cold shock fluid of the chlD mutant was only about twice that for the wild-type. This experiment indicated that most of the $\mathrm{MoO}_{4}^{2-}$ accumulated by the $c h l D$ strain was associated with the outer membrane, which would explain the high level of $\mathrm{MoO}_{4}^{2-}$ accumulated by the chlD cells at the beginning of the assay. In parallel experiments, the $\mathrm{MoO}_{4}^{2-}$ level found in the cytoplasm corresponded exactly to the amount of $\mathrm{MoO}_{4}^{2-}$ transported during the second phase of the uptake curve, while externally bound molybdate corresponded to the amount of the first phase.

\section{Effect of molybdate concentration on the uptake rate}

The kinetic parameters of the molybdenum intracellular uptake system (phase 2) were determined by varying the external concentration of molybdate at $\mathrm{pH} 6.5$. The zero value of phase 2 was determined by graphical extrapolation (at molybdate concentrations higher than $10 \mathrm{~nm})$. The maximum accumulation values are proportional to initial transport rates (Kepes, 1978). In the chlD strain, both parameters exhibited saturation behaviour and were, therefore, used to determine $K_{\mathrm{m}}$ values which were close $\left(2.7 \times 10^{-8} \mathrm{M}\right.$ and $\left.2.5 \times 10^{-8} \mathrm{M}\right)$. 


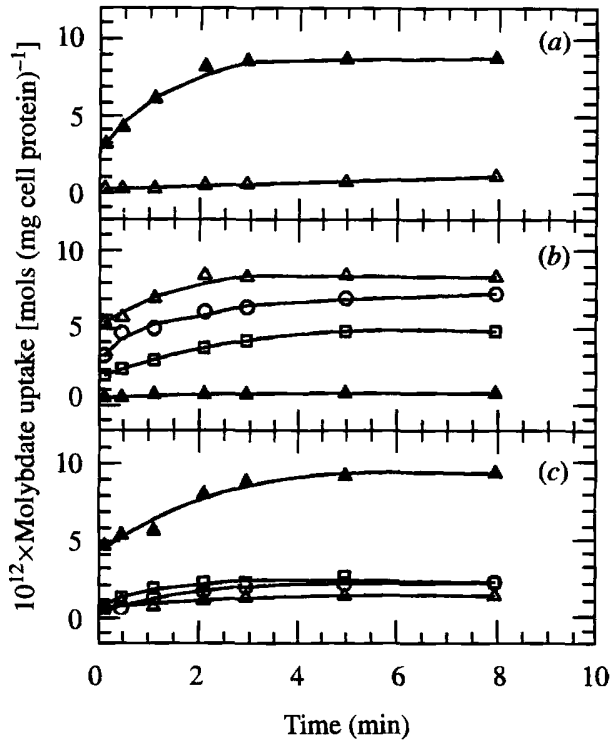

Fig. 4. Molybdenum uptake by cells of the chlD strain grown in medium containing different molybdate concentrations. General conditions were as in Fig. 1. (a) Cells were grown with $10^{-6} \mathrm{M}$-molybdate $(\Delta)$ or with no molybdate $(\Delta)$ in the culture medium. (b) Cells were first grown with $10^{-6} \mathrm{M}$-molybdate $(\boldsymbol{\Delta})$ and then transferred to molybdate-free medium and assayed $1(\square), 3(O)$ and $4(\triangle) \mathrm{h}$ after transfer. (c) Cells were first grown in a molybdate-free medium $(\boldsymbol{\Delta})$ and then transferred to a medium which contained $10^{-6} \mathrm{M}$-molybdate; uptake was assayed after $1(\square), 3(O)$ and $4(\triangle)$ h.

The $K_{\mathrm{m}}$ value for $\mathrm{MoO}_{4}^{2-}$ was found to increase with $\mathrm{pH}$ from $1.45 \times 10^{-8} \mathrm{M}$ at $\mathrm{pH} 6.0$ to $4.55 \times 10^{-8} \mathrm{M}$ at $\mathrm{pH} 7.0$. The general features of this $\mathrm{pH}$ dependence support a protonation of some site in the transport system, which would be necessary for the binding of $\mathrm{MoO}_{4}^{2-}$ to the enzyme. The apparent $\mathrm{p} K_{\mathrm{a}}$ of this ionizable group was 6.7 .

\section{Effect of molybdate concentration in the culture medium}

High molybdate concentrations are known to decrease uptake capacity in Clostridium pasteurianum (Elliot \& Mortenson, 1976). Therefore the chlD strain was cultivated at several molybdate concentrations and assayed for uptake. Uptake was optimal in cells grown at molybdate concentrations below $10^{-8} \mathrm{M}$ and was almost completely abolished in cells grown at $10^{-6} \mathrm{M}$-molybdate (Fig. 4a), in agreement with Miller et al. (1987). This is unlikely to be due to competition between ${ }^{99} \mathrm{Mo}$ and nonradioactive molybdenum since, in the chlD strain, previously taken-up $\mathrm{MoO}_{4}^{2-}$ should have been chased from the cell by the repeated washings. When cells were grown in the presence of high molybdate concentrations and then transferred to a medium free of molybdate, the uptake capacity was slowly restored by growth in the new medium (Fig. $4 b$ ). A control with chloramphenicol $\left(150 \mu \mathrm{g} \mathrm{ml}^{-1}\right)$ in the molybdate-free medium showed no restoration of uptake capacity. Conversely, when cells were grown in a molybdate-free medium and then transferred to a new medium containing $1 \mu \mathrm{M}-\mathrm{MoO}_{4}^{2-}$, the uptake capacity was lost (Fig. $4 c$ ).

\section{Discussion}

We have shown here that molybdenum enters the cytoplasm of cells after an incubation with low concentrations of radioactive $\mathrm{MoO}_{4}^{2-}$. Typically, each cell could take up about 500 atoms of molybdenum when incubated in the presence of $10-20 \mathrm{nM}-\mathrm{MoO}_{4}^{2-}$. The kinetics of assimilation were complex and apparently the result of both a rapid binding to an outer component of the cell and an intracellular enzyme-dependent uptake.

The first phase of uptake was defined as binding because it was almost instantaneous and was not decreased at $0^{\circ} \mathrm{C}$. This is likely to be a specific binding to a receptor as sulphate ion did not affect it, and molybdate-repressed cells, thoroughly washed, did not show this phenomenon. EDTA treatment removed the same amount of $\mathrm{MoO}_{4}^{2-}$ as was bound to the cells during phase 1 of uptake, indicating a likely location of the receptor on the outer membrane and not in the periplasm. Cells previously treated with EDTA were unable to take up $\mathrm{MoO}_{4}^{2-}$, indicating that the outer membrane receptor is a necessary component of the uptake system. A similar biphasic uptake was observed during vitamin $B_{12}$ transport and the initial phase was shown to represent binding to a receptor protein embedded in the outer membrane (DiGirolamo \& Bradbeer, 1971; Bradbeer \& Woodrow, 1976).

The second phase corresponds to the entry of the molybdenum into the cytoplasm. The time-course and the temperature-dependence are typical of metabolic events. The question of the chemical nature of the molybdenum transported into the cell must be considered. In effect, molybdenum is not metabolically required as molybdate, but as a complex of molybdenum (in an unknown valence and chemical state) with a sulphur-containing pterin (Johnson \& Rajagopalan, $1987 \mathrm{~b}$ ). In the chlD strain, internal ${ }^{99} \mathrm{Mo}$ was readily exchanged with external non-radioactive $\mathrm{MoO}_{4}^{2-}$. Assuming that $\mathrm{MoO}_{4}^{2-}$ was not chemically modified outside the cytoplasm, these observations indicate that an equilibrium exists between cytoplasmic molybdenum and external $\mathrm{MoO}_{4}^{2-}$. It is possible, although we have no direct proof, that molybdenum enters the cytoplasm as $\mathrm{MoO}_{4}^{2-}$ which is then the substrate for the synthesis of the molybdo-cofactor (Hinton \& Dean, 1990).

Although the chlD locus is generally considered to be involved in the uptake of molybdenum (Johann \& Hinton, 1987; Scott \& Amy, 1989), our chlD strain does not appear to be affected in the main permeation 
function, but rather in a function involved in the metabolism of the transported molybdenum. The properties of the uptake system in the chlD strain can be summarized as follows. It is an active process since the cytoplasm of these cells accumulated up to 30 times more molybdenum than in the medium. An energy source was necessary. Arsenate $(5 \mathrm{mM}$, in the presence of $10 \mathrm{~mm}-$ phosphate) could abolish $70 \%$ of the permeation process (phase 2 of the kinetics) without affecting the binding phase (phase 1), implying that this represents a specific effect on molybdate uptake. However, although this inhibition may indicate an ATP-dependent system, it cannot be considered as a proof since arsenate may have additional effects (Ames et al., 1990). The $K_{\mathrm{m}}$ value for the uptake is about $2.7 \times 10^{-8} \mathrm{M}$ at $\mathrm{pH} 6.5$ and $\mathrm{pH}$ greatly affected the $K_{\mathrm{m}}$. A p $K_{\mathrm{a}}$ of 6.7 was determined, which might indicate the involvement of a histidine residue in some component of the uptake system. The high affinity of the system is consistent with the natural concentration of molybdate, the only soluble source of molybdenum, which is about $10^{-7} \mathrm{M}$ in sea water and generally lower in river water (Pope et al., 1980).

The molybdate binding activity detected in the periplasmic fluid, together with the differential effects of arsenate and CCCP on molybdate uptake, supports the classification of the molybdate uptake system among the shock-sensitive systems (Berger \& Heppel, 1974; Ames, 1986). It would then belong to the recently defined 'traffic ATPases' (Ames et al., 1990), which include many bacterial and eukaryotic transport systems. All these systems contain a periplasmic substrate-binding protein and, generally, three membrane-bound proteins which form a permeation complex in the cytoplasmic membrane. One of these three proteins is hydrophilic, carries an ATP-binding site and is generally thought to be involved in energy coupling. In most cases these four proteins are encoded by a single operon. In agreement with our proposal that molybdate transport belongs to the ATP-dependent periplasmic binding protein systems, the presence of at least four loci in the chlD region was suggested (Hinton \& Dean, 1990), one of them presenting high sequence homology with the family of his $P$ and malK genes (Johann \& Hinton, 1987). It is then to be expected that one of these loci will be the structural gene of the molybdate binding protein, corresponding to the molybdate binding activity detected in the periplasmic fluid.

Sulphate inhibits molybdate transport (Elliot \& Mortenson, 1975) and correspondingly, molybdate inhibits sulphate uptake probably due to competition (Tweedie \& Segal, 1970). Although sulphate transport has been little studied in $E$. coli, it is known to be common to selenate and selenite (Lindblow-Kull et al., 1985). The effect of molybdate is not known, but the $K_{\mathrm{m}}$ value of $3 \mu \mathrm{M}$ for sulphate does not support the idea that molybdate can be efficiently transported by this system. In Salmonella typhimurium, the sulphate transport system ( $K_{\mathrm{m}}$ for sulphate is $474 \mu \mathrm{M}$ ) is essentially unaffected by the addition of molybdate (Pardee et al., 1966). These observations imply that the present system is a genuine molybdate transport system.

The molybdate transport capacity of the chlD strain depended on the molybdate concentration in the medium, which suggests that the chlD operon and, therefore, the expression of the molybdate transport system, would be repressed at high molybdate concentrations and fully expressed when no molybdate is available.

The expression of all the components of the molybdate transport system could also depend on two different genetic regions: $c h l D$ and one other corresponding to the outer membrane receptor, porin-like protein (Kadner \& Bassford, 1978). In effect, the data concerning the distribution of molybdate in the $c h l D$ and wild-type strains indicate a derepression of the synthesis of the outer membrane receptor, but little, if any, of the periplasmic components. This difference indicates a different genetic location, in agreement with the information available for other transport systems where an outer membrane receptor is involved (Kadner \& Bassford, 1978). A recently described new gene, $m o l R$, could be a potential candidate (Lee et al., 1990).

The authors thank Dr J. DeMoss for his advice during the writing of this paper. The work received financial support from the CDCHT (C-212) of the Universidad de Los Andes.

\section{References}

Adhya, S., Cleary, P. \& Campbell, A. (1968). A detection analysis of prophage lambda and adjacent genetic regions. Proceedings of the National Academy of Sciences of the United States of America 61, 956-962.

AMES, G. F.-L. (1986). Bacterial periplasmic transport systems: structure, mechanism and evolution. Annual Review of Biochemistry 55, $397-425$.

Ames, G. F.-L., Mimura, C. S. \& Shyamala, V. (1990). Bacterial periplasmic permeases belong to a family of transport proteins operating from Escherichia coli to human: Traffic ATPases. FEMS Microbiology Reviews 75, 429-446.

BERGER, E. A. (1973). Different mechanisms of energy coupling for the active transport of proline and glutamine in Escherichia coli. Proceedings of the National Academy of Sciences of the United States of America 70, 1514-1518.

BERGER, E. A. \& HEPPEL, L. A. (1974). Different mechanisms of energy coupling for the shock-serusitive and shock-resistant amino acid permeases of Escherichia coli. Journal of Biological Chemistry 249, 7747-7755.

BRADBEER, C. \& WoOdRow, M. L. (1976). Transport of vitamin $B_{12}$ in Escherichai coli: energy dependence. Journal of Bacteriology 128, 99-104.

del Campillo-Campbell, A. \& Campbell, A. (1982). Molybdenum cofactor requirement for biotin sulfoxide reduction in Escherichia coli. Journal of Bacteriology 149, 469-478.

CASSE, F. (1970). Mapping of the gene chlB controlling membrane bound nitrate reductase and formic hydrogen-lyase activities in 
Escherichia coli K-12. Biochemical and Biophysical Research Communications 39, 429-436.

Cuppoletti, J. \& Segel, I. H. (1975). Kinetics of sulfate transport by Penicillium notatum. Interactions of sulfate, protons, and calcium. Biochemistry 14, 4712-4718.

DAGERT, M. \& PUIG, J. (1976). Mapeo del gen chlE en Escherichia coli K-12. Acta Cientifica Venezolana 27, 85-87.

DiGirolamo, P. M. \& Bradbeer, C. (1971). Transport of vitamin $B_{12}$ in Escherichia coli. Journal of Bacteriology 106, 745-750.

Dubourdieu, M., Andrade, E. \& Puig, J. (1976). Molybdenum and chlorate resistant mutants in Escherichia coli K-12. Biochemical and Biophysical Research Communications 70, 766-773.

Eady, R. R. \& Postgate, J. R. (1974). Nitrogenase. Nature, London 249, 805-810.

Elliot, B. B. \& MoRTenson, J. R. (1975). Transport of molybdate by Clostridium pasteurianum. Journal of Bacteriology 124, 1295-1301.

ELLIOT, B. B. \& MORTENSON, J. R. (1976). Regulation of molybdate transport by Clostridium pasteurianum. Journal of Bacteriology 127, 770-779.

ENOCH, H. G. \& LESTER, R. L. (1975). The purification and properties of formate dehydrogenase and nitrate reductase from Escherichia coli. Journal of Biological Chemistry 250, 6693-6705,

FoRGET, P. (1974). The bacterial nitrate reductase: solubilization, purification and properties of the enzyme A of Escherichia coli K-12. European Journal of Biochemistry 42, 325-332.

Giordano, G., Grillet, L., Pommier, J., Terriere, C., Haddock, B. A. \& Azoulay, E. (1980). Precursor forms of the subunits of nitrate reductase in chlA and $c h l B$ mutants of Escherichia coli K-12. European Journal of Biochemistry 105, 297-306.

Glaser, J. H. \& DeMoss, J. A. (1971). Phenotypic restoration by molybdate of nitrate reductase activity in chlD mutants of Escherichia coli. Journal of Bacteriology 108, 854-860.

GLASER, J. H. \& DeMoss, J. A. (1972). Comparison of nitrate reductase mutants of Escherichia coli selected by alternative procedures. Molecular and General Genetics 116, 1-10.

IIDA, K. \& TANIGUCHI, S. (1959). Particulate electron transport system to nitrate and its solubilization. Journal of Biochemistry 46, 1041-1055.

Hinton, S. M. \& DEAN, D. (1990). Biogenesis of molybdenum cofactors. Critical Reviews in Microbiology 17, 169-188.

JoHANN, S. \& Hinton, S. M. (1987). Cloning and nucleotide sequence of the chlD locus. Journal of Bacteriology 169, 1911-1916.

Johnson, M. E. \& RAJAGOPALAN, K. V. (1987a). In vitro system for molybdopterin biosynthesis. Journal of Bacteriology 169, 110-116.

JoHnson, M. E. \& RaJaGopalan, K. V. (1987b). Involvement of chla, $E, M$ and $N$ loci in Escherichia coli molybdopterin biosynthesis. Journal of Bacteriology 169, 117-125.

Johnson, J. L., Hainline, B. E. \& Rajagopalan, K. V. (1980). Characterization of the molybdenum cofactor of sulfite oxidase, xanthine oxidase and nitrate reductase. Journal of Biological Chemistry 255, 1783-1786.

Johnson J. L., Hainline, B. E., Rajagopalan, K. V. \& ARison, B. H. (1984). The pterin component of the molybdenum cofactor: structural characterization of two fluorescent derivatives. Journal of Biological Chemistry 259, 5414-5422.

KADNER, R. J. \& BASSFORD, P. J., JR (1978). The role of the outer membrane in active transport. In: Bacterial Transport, pp. 413-462. Edited by B. R. Rosen. New York: Marcel Dekker.

KEPES, A. (1978). La permease à lactose. In Aspects Moleculaires des Fonctions Membranaires, pp. 115-149. Edited by A. Kepes. Paris: Masson.

KLEIN, W. L. \& BOYER, P. D. (1972). Energization of active transport by Escherichia coli. Journal of Biological Chemistry 247, 7257-7265.

LeE, J. H., WendT, J. C. \& ShanmugaM, K. T. (1990). Identification of a new gene, molR, essential for utilization of molybdate by Escherichia coli. Journal of Bacteriology 172, 2079-2087.
Lindblow-Kull, C., Kull, F. J. \& Shrift, A. (1985). Single transporter for sulfate, selenate and selenite in Escherichia coli K-12. Journal of Bacteriology 163, 1267-1269.

LUND, K. \& DeMoss, J. A. (1976). Association-dissociation behavior and subunit structure of heat-solubilized nitrate reductase from Escherichia coli. Journal of Biological Chemistry 251, 2207-2216.

MACGREgor, C. H. \& Schnaitman, C. A. (1973). Reconstitution of nitrate reductase activity and formation of membrane particles from cytoplasmic extracts of chlorate-resistant mutants of Escherichia coli. Journal of Bacteriology 114, 1164-1176.

Miller, J. B. \& AMY, N. K. (1983). Molybdenum cofactor in chlorateresistant and nitrate reductase deficient insertion mutants of Escherichia coli. Journal of Bacteriology 155, 793-801.

Miller, J. B., ScotT, D. J. \& AMY, N. K. (1987). Molybdenumsensitive transcriptional regulation of the chlD locus of Escherichia coli. Journal of Bacteriology 169, 1853-1860.

Neu, H. C. \& HePPEL, L. A. (1965). The release of enzymes from Escherichia coli by osmotic shock and during the formation of spheroplasts. Journal of Biological Chemistry 240, 3685-3692.

Pardee, A. B., Prestidge, L. S., Whipple, M. B. \& Dreifuss, J. (1966). A binding site for sulfate and its relation to sulfate transport in Salmonella typhimurium. Journal of Biological Chemistry 241, 3962-3969.

Pichinoty, F. (1964). A propos des nitrate-reductases d'une bactérie dénitrifiante. Biochimica et Biophysica Acta 89, 378-381.

PIEnkos, P. T. \& BrILL, W. J. (1981). Molybdenum accumulation and storage in Klebsiella pneumoniae and Azotobacter vinelandii. Journal of Bacteriology 145, 743-751.

Pope, M. T., Still, E. R. \& Williams, R. J. P. (1980). A comparison between the chemistry and biochemistry of molybdenum and related elements. In Molybdenum and Molybdenum-containing Enzymes, pp. 1-4. Edited by M. Coughlan. Oxford: Pergamon Press.

Puig, J. \& Azoulay, E. (1967). Étude génétique et biochimique des mutants résistants au $\mathrm{ClO}_{3}^{-}$. Comptes Rendus de TAcademie des Sciences, Paris 264, 1916-1918.

Ruiz-Herrera, J. \& DeMoss, J. A. (1969). Nitrate reductase complex of Escherichia coli K-12: participation of specific formate dehydrogenase and cytochrome $b_{1}$ components in nitrate reduction. Journal of Bacteriology 99, 720-729.

Sanchez, J. A., Dubourdieu, M. \& Chippaux, M. (1979). Localization and characterization of cytochromes from membrane vesicles of Escherichia coli K-12 grown in anaerobiosis with nitrate. Biochimica et Biophysica Acta 547, 198-210.

ScotT, D. \& AMY, N. K. (1989). Molybdenum accumulation in chlD mutants of Escherichia coli. Journal of Bacteriology 171, 1284-1287.

SEDMAK, J. J. \& GROSBERG, S. E. (1977). A rapid, sensitive and versatile assay for protein using Coomassie Brilliant Blue G250. Analytical Biochemistry 79, 544-546.

SHAH, V. K. \& BRILL, W. J. (1977). Isolation of an iron-molybdenum cofactor from nitrogenase. Proceedings of the National Academy of Sciences of the United States of America 74, 3249-3253.

SPERL, G. T. \& DeMoss, J. A. (1975). chlD gene function in molybdate activation of nitrate reductase. Journal of Bacteriology 122, 1230-1238.

StEWART, V. (1982). Requirement for Fnr and NarL functions for nitrate reductase expression in Escherichia coli. Journal of Bacteriology 151, 1320-1325.

StewarT, V. \& MACGRegor, C. H. (1982). Nitrate reductase in Escherichia coli K-12: involvement of chlC, chlE and chlG loci. Journal of Bacteriology 151, 788-789.

TweEdIE, J. V. \& SEGEL, I. H. (1970). Specificity of transport processes for sulfur, selenium and molybdenum anions by filamentous fungi. Biochimica et Biophysica Acta 196, 95-106.

Venables, W. A. \& GUEST, J. R. (1968). Transduction of nitrate reductase loci of Escherichia coli by phages P1 and lambda. Molecular and General Genetics 103, 127-140.

Yoshi, A. K., AHmed, S. \& AmES, G. F.-L. (1989). Energy coupling in bacterial periplasmic transport systems. Journal of Biological Chemistry 264, 2126-1233. 